\title{
Charcoal kiln sites, associated landscape attributes and historic forest conditions: DTM-based investigations in Hesse (Germany)
}

\author{
Marcus Schmidt ${ }^{1}$, Andreas Mölder ${ }^{1 *} \mathbb{D}$, Egbert Schönfelder ${ }^{1}$, Falko Engel ${ }^{1}$ and Werner Fortmann-Valtink ${ }^{2}$
}

\begin{abstract}
Background: An examination of the distribution of ancient charcoal kiln sites in the forest landscape seems to be worthwhile, since general trends in the selection of suitable kiln site locations in the past might become obvious. In this way forest landscape elements with a more intense usage by charcoal burning can be identified. By doing this, we can expect to gain information on the former condition and tree species composition of woodland. Investigations on the spatial distribution of charcoal kiln sites in relation to landscape attributes are sparse, however, probably due to the high on-site mapping effort. The outstanding suitability of LiDAR-derived digital terrain models (DTMs) for the detection of charcoal kiln sites has been recently proved. Hence, DTM-based surveys of charcoal kiln sites represent a promising attempt to fill this research gap.

Methods: Based on DTM-based surveys, we analyzed the spatial distribution of charcoal kiln sites in two forest landscapes in the German federal state of Hesse: Reinhardswald and Kellerwald-Edersee National Park. In doing so, we considered the landscape attibutes "tree species composition", "water supply status", "nutrient supply status", "soil complex classes", "altitude", "exposition", and "inclination".
\end{abstract}

Results: We found that charcoal kiln sites were established preferably on hillside locations that provided optimal growing and regeneration conditions for European beech (Fagus sylvatica) due to their acidic brown soils and sufficient water supply. These results are in line with instructions for the selection of appropriate kiln site locations, found in literature from the 18th to the 19th century.

Conclusions: We conclude that there were well-stocked, beech-dominated deciduous forest stands in northern Hesse before 1800, particularly at poorly accessible hillside locations. These large stocks of beech wood were utilized by the governments of the different Hessian territories through the establishment of ironworks and hammer mills. Our argumentation is well in line with findings which underline that not all Hessian forests were overexploited in the 18th century. Frequently repeated complaints about "wood shortage" seemed to be more a political instrument than reality, not only in Hesse, but all over Europe. Consequently, a differentiated assessment of woodland conditions in proto-industrial times is strictly advised, even if contemporary sources draw a dark picture of the historic situation.

Keywords: Airborne laser scanning, Charcoal production, Cultural remains, Digital terrain model, Fagus sylvatica, Forest history, Historical ecology, Landscape history, Industrial history, Metallurgy

\footnotetext{
* Correspondence: moelder@gmx.de

${ }^{1}$ Northwest German Forest Research Institute, Department A (Forest Growth),

Grätzelstraße 2, D-37079 Göttingen, Germany

Full list of author information is available at the end of the article
}

\section{说) Springer}

(c) 2016 Schmidt et al. Open Access This article is distributed under the terms of the Creative Commons Attribution 4.0 International License (http://creativecommons.org/licenses/by/4.0/), which permits unrestricted use, distribution, and reproduction in any medium, provided you give appropriate credit to the original author(s) and the source, provide a link to the Creative Commons license, and indicate if changes were made. 


\section{Background}

Until the use of coal-derived coke became widespread from the late 18th century onwards, the only suitable fuel for ore smelting or forging was charcoal (Reuter 1833; Hammersley 1973; Collin and Wetzel 2004). In most parts of Europe, the production of charcoal was mainly conducted on-site in the forest, where the use of temporary kilns was common (Schwappach 1886; Rösler et al. 2012; Deforce et al. 2013; Risbøl et al. 2013). Charcoal kilns consist of a carefully stacked wood pile which is covered by a gas-tight layer of soil, turf and moss (Cancrinus 1767; Klein 1836; von Berg 1860; Armstrong 1978; Bonhôte et al. 2002). Since the foundation of charcoal kilns is typically horizontal and of circular shape, the remains of these charcoal production sites can be detected quite easily, not only on-site in the forest or in open land (Hillebrecht 1982; Bonhôte et al. 2002; Prus 2005; Ludemann 2010), but also on digital terrain models (DTMs) (Gertloff 2011; Ludemann 2012; Deforce et al. 2013; Hesse 2013; Risbøl et al. 2013; Raab et al. 2015).

The outstanding suitability of DTMs for the detection of charcoal kiln sites has been shown by several recent studies. Risbøl et al. (2013) who evaluated the detection success rates for cultural remains that were located manually based on the interpretation of DTMs, found that charcoal kiln sites could be classified correctly with a high hit rate in Norwegian forests. Even in northern Belgium, a region with a very flat topography, DTMs were shown to be a very suitable tool for locating ancient charcoal production sites (Deforce et al. 2013). Ludemann (2012) stated that the results of DTM interpretation rapidly quadrupled the number of already known kiln sites in parts of the Black Forest (southwest Germany), which have been mapped in approximately 20 years of field studies. The high kiln site density in this region, which was also emphasized by Bofinger and Hesse (2011) and Hesse (2013), now amounts to more than 100 objects per 100 ha (Ludemann 2012). Unexpectedly high kiln site densities were also reported by Raab et al. (2015), who conducted DTM-based surveys in Lower Lusatia (eastern Germany) and concluded that charcoal production sites are an underestimated feature in modern landscapes of the north German lowlands.

Anthracological studies of charcoal kiln sites have been conducted in many regions in recent decades (Krause 1972; Hillebrecht 1982; Bonhôte et al. 2002; Ludemann 2003; Klemm et al. 2005; Nölken 2005; Knapp et al. 2013; Samojlik et al. 2013). However, investigations on the spatial distribution of charcoal kiln sites in relation to landscape attributes such as exposition, inclination or soil conditions are sparse (Bonhôte et al. 2002; Ludemann 2003; Bofinger and Hesse 2011; Samojlik et al. 2013), probably due to the high mapping effort. DTM-based surveys of charcoal kiln sites represent a promising attempt to fill this research gap.

A closer examination of the distribution of charcoal kiln sites in the forest landscape seems to be worthwhile, since general trends in the selection of suitable kiln site locations in the past might become obvious. In this way forest landscape elements with a more intense usage by charcoal burning can be identified. By doing this, we can expect to gain information on the former condition (i.e., the silvicultural and ecological state) and tree species composition of woodland, since charcoal makers and consumers needed particular types of wood and a constant wood supply (von Berg 1860; Hammersley 1973; Reinhardt 1999). The location of charcoal kiln sites can also be discussed in relation to the situation of charcoal consumers, especially ironworks (Bofinger and Hesse 2011). Finally, the detailed instructions for the selection of appropriate kiln site locations, found in the literature from the 18th and 19th century (von Carlowitz 1732; Klein 1836; von Berg 1860), can be compared with the actual situation in the forest in terms of DTM-derived information on the location of charcoal kiln sites.

In line with these considerations, we analyze the spatial distribution of charcoal kiln sites in two forest landscapes in the German federal state of Hesse, in the middle-German highlands. These two forest landscapes, namely the Reinhardswald and the Kellerwald-Edersee National Park, are very suitable study areas due to a wealth of data on landscape attributes, forest stands, site conditions, and early industrial history. High-resolution DTMs are available for these areas and both forest landscapes border historic ironworks for which we have good written information on production history and charcoal consumption.

This study aims at answering the following questions:

- Are there relationships between the distribution of charcoal kiln sites and particular landscape attributes?

- What are the relationships between the distribution of charcoal kiln sites and the main charcoal consumers?

- What conclusions can be drawn with regard to woodland conditions and tree species composition at the time of charcoal production?

\section{Methods}

\section{Regional setting of the study areas}

\section{Geographical and historical setting}

The two study areas, the Reinhardswald and the Kellerwald-Edersee National Park, are about $60 \mathrm{~km}$ apart from one another. They are located in the northern part of Hesse, a German federal state characterized by low mountain landscapes and a high proportion (42\%) of 
woodland cover (Fig. 1). The climate can be characterized as subatlantic with low subcontinental influence. In both study areas, natural woodlands would be dominated by European beech (Fagus sylvatica), with some exceptions at moist, wet or extremely dry sites and steep, rocky slopes, which are characterized by black alder (Alnus glutinosa) and birches (Betula spp.) or oaks (Quercus robur and Q. petraea), respectively (BfN 2010).

The Reinhardswald is bordered by the rivers Fulda, Weser and Diemel and represents the northernmost connected forest area of Hesse. The study area is 20,600 ha in size. The underlying bedrock is predominantly sandstone from the Buntsandstein, a lithostratigraphic unit of the Lower Triassic series (Rapp 2002).

The Kellerwald-Edersee National Park is located south of the river Eder, whose deeply incised valley has been flooded by a $27-\mathrm{km}$ long artificial lake (Edersee) since 1914, when the Eder was dammed. The national park is 5700 ha in size and was established in 2004 with the aim of protecting large, unfragmented areas of semi-natural acidophilous beech forests and other deciduous forest types. The underlying bedrock is mainly composed of Carboniferous clay shale and greywacke. Since 2011, about 1500 ha of the Kellerwald-Edersee National Park are part of the UNESCO World Heritage Site "Primeval Beech Forests of the Carpathians and the Ancient Beech
Forests of Germany" (Succow et al. 2012; Vološčuk 2014; Menzler and Sawitzky 2015).

According to forest site survey data, the site conditions are dominated by acidic soils with mesotrophic nutrient status in both study areas. The western parts of the Reinhardswald are characterized by flat or gently sloping plateaus, where seasonally moist soils predominate. While fresh (moderately fresh, fresh or markedly fresh) soils are largely missing on these flatter areas, they are much more abundant on the slopes of the eastern parts of the Reinhardswald (Bonnemann 1984; Rapp 2002). In the Kellerwald-Edersee National Park, moderately dry, moderately fresh and fresh sites prevail and almost no seasonally moist or moist soils occur (Menzler and Sawitzky 2015).

In high medieval times (ca. AD 1100 to 1300), large parts of both study areas were not covered by forest, but used as agricultural land. Relicts of ancient fields and lynchets (i.e., banks of earth that build up on the downslope of a field ploughed over a long period of time), which are visible in the field as well as in DTMs (Fig. 2), provide strong evidence for the former agricultural land use. From the early 14th century onwards, the associated settlements and their fields were abandoned due to a complex of causes, particularly climate deterioration and epidemic plagues. Forest spread out quite quickly, and already in the mid-15th

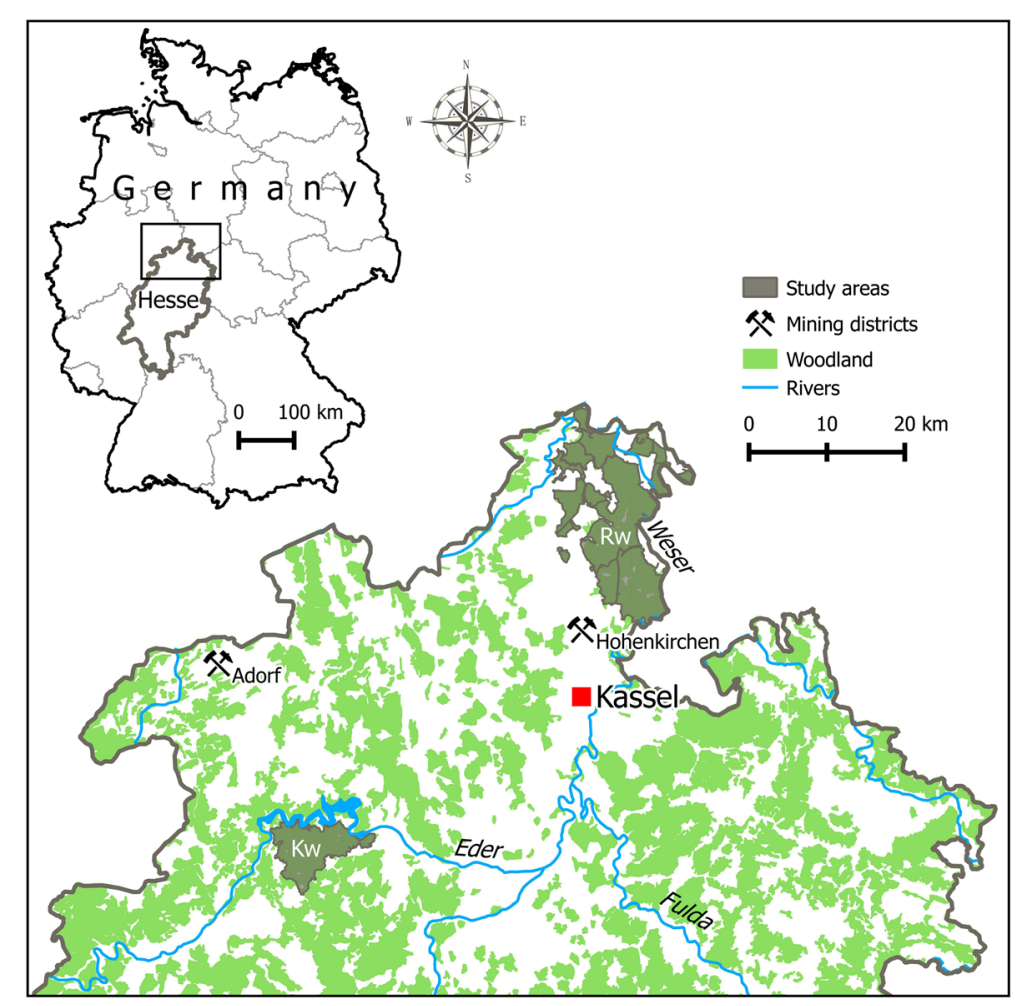

Fig. 1 The location of the study areas discussed in this paper. Rw: Reinhardswald, Kw: Kellerwald-Edersee National Park 


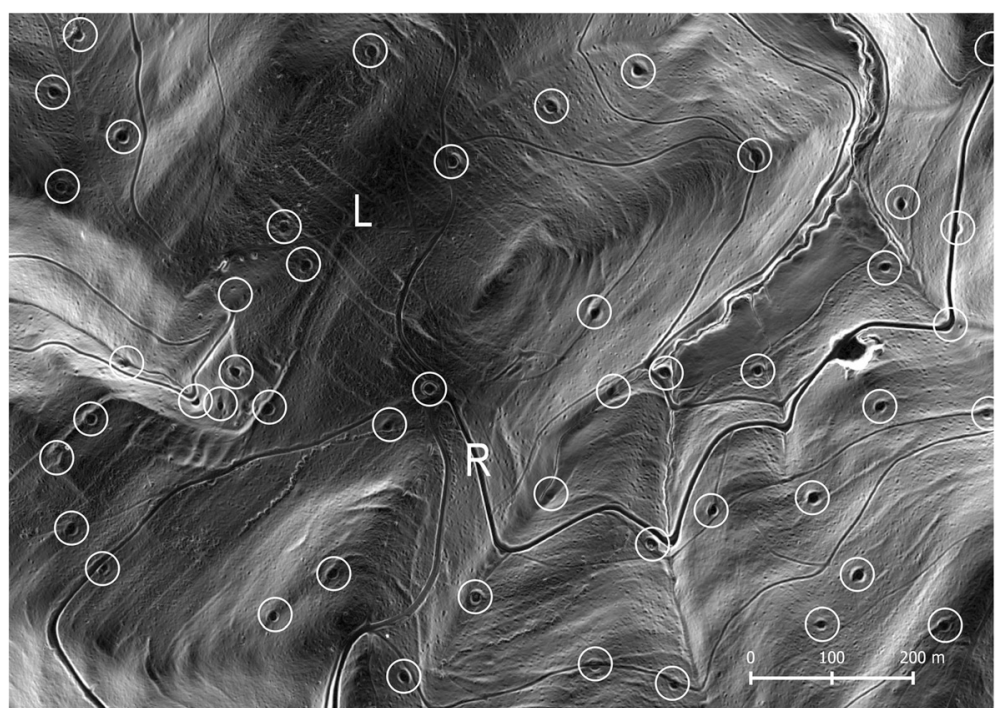

Fig. 2 Detail of a digital terrain model (DTM) derived from airborne laser scanning (ALS) data, Kellerwald-Edersee National Park. Besides numerous charcoal kiln sites (marked by white circles), medieval lynchets (one example marked with "L") and modern forest roads (one example marked with " $\mathrm{R}$ ") are visible. The area is currently mostly covered by beech forest

century dense woodland had re-covered the landscape (Höhle 1929; Jäger 1951; Jäger 1958; Born 1961; Bonnemann 1984; Stephan 2010). As relatively accurate topographic maps, the scale is at least 1:100,000, from the 18th century (Reinhardswald: Leopold 1719; Rüstmeister 1724) and early 19th century (KellerwaldEdersee National Park: von Le Coq 1805) show, both study areas were almost completely covered with deciduous forest stands, interspersed with small meadows and heathlands. At this time, the portion of coniferous forests was less than 1 \% (Mackeldey 1971; Zarges 1999).

Today, the forest vegetation is dominated by beech, with shares of about $40 \%$ in the Reinhardswald and $66 \%$ in the Kellerwald-Edersee National Park. The portion of oaks is $17 \%$ in the Reinhardswald and $7 \%$ in the Kellerwald-Edersee National Park. Coniferous tree species, mainly spruce (Picea abies), reach total covers of $40 \%$ in the Reinhardswald and $20 \%$ in the Kellerwald-Edersee National Park.

Both forest areas are nowadays owned by the federal state of Hesse. The whole Reinhardswald area belonged for centuries to the Landgraviate of Hesse-Kassel. Ownership transferred in 1803 to the Electorate of Hesse, which was merged into the Prussian province of Hesse-Nassau in 1866 (Bonnemann 1984). In contrast, the area of the current Kellerwald-Edersee National Park was divided between three different territories for a long time (Fig. 3). The larger eastern part was ruled by the County of Waldeck (since 1712 Principality of Waldeck) and was not merged into the Prussian province of Hesse-Nassau until 1929. The smaller western part (Itter estate) belonged to the Landgraviate of Hesse-Marburg from 1589, and was later assigned to the Landgraviate of Hesse-Darmstadt (since 1806 Grand Duchy of Hesse). This part was also merged into the Prussian province of Hesse-Nassau in 1866. A small area at the southern edge of the Kellerwald-Edersee National Park belonged, like the Reinhardswald, to the Landgraviate of Hesse-Kassel (Curtze 1850; Demandt 1972; Waldeyer 2014).

\section{Pre- and early industrial charcoal burning and customers in the study areas}

From the middle of the 16th century onwards, smelting works and hammer mills were established in the vicinity of the studied forest areas. Prior to this period, iron and iron products were made in small, decentralized smelting furnaces and smithies (Wick 1910; Sippel 2005). From the mid-17th century, the charcoal makers used temporary charcoal kilns on-site in the forest coupes. These charcoal kilns consisted of a carefully stacked wood pile which was covered by a gas-tight layer of soil, turf and moss (Klein 1836; von Berg 1860). Previously, the production of charcoal took place in charcoal pits (Schäfer 1977; Wick 1910). For these reasons, we conclude that the majority of the charcoal kiln sites in both study areas were established between the mid-17th century and the end of the 19th century. In the following section, we summarize the main developments with regard to charcoal and iron production in the study areas.

\section{Reinhardswald}

The first written evidence of charcoal making dates from 1302 (Bonnemann 1984). A number of later archival 


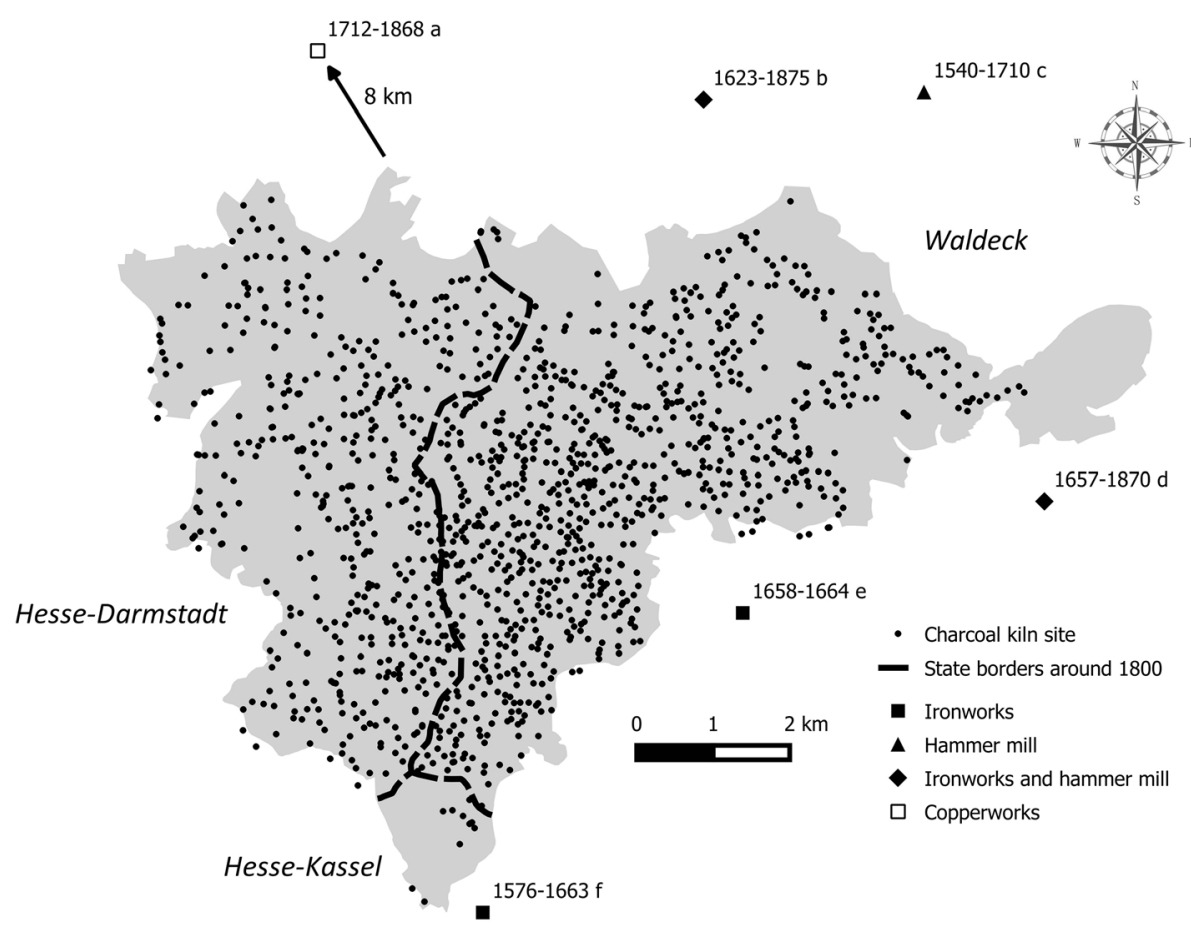

Fig. 3 The study area Kellerwald-Edersee National Park with the location of the mapped charcoal kiln sites, historical industrial sites, and historical state boundaries. The different ironworks and hammer mills of the Haina Hospital are not illustrated, since they obtained no charcoal or fuelwood from the study area. a: Thalitter, b: Bericher Faktorei, c: Vornhagen, d: Kleinern, e: Gellershausen, f: Frankenau

documents indicate that secondary woodland, which had developed after the abandonment of farmland in medieval times, was cleared for agriculture in the 16th century. The harvested wood was used for glass and charcoal production (Jäger 1951). Forest decrees issued by the Landgraviate of Hesse-Kassel in 1593, 1629 and 1683 highlight that there was a huge amount of lying wood (originating from windthrow, for example) which should be used for charcoal production. But also regularly harvested wood was otherwise carbonized. Trees that were suitable for timber production or technical purposes must not be allocated to the charcoal makers (Landgraf zu Hessen 1593; Landgraf zu Hessen 1629; Landgraf zu Hessen 1683).

The main customers of charcoal were the initially privately operated hammer mills and ironworks at Lippoldsberg (1555-1873, since 1583 state-owned) and Heisebeck (1555-ca. 1564), and the state-owned ironworks at Vaake (1581-1583), Knickhagen (1591-1666), and Veckerhagen (1666-1903). From about 1700 to 1730, a copperworks existed at the Olbetal near Veckerhagen (Fig. 4). Following a forest description from 1774 , an annual wood volume of ca. $1200 \mathrm{~m}^{3}$ could be sustainably harvested in the ca. 120-ha forest compartment "Stickelhalbe" to provide charcoal for the hammer mill at Lippoldsberg (Henne 1997). By 1767, the
Veckerhagen ironworks needed ca. $4800 \mathrm{~m}^{3}$ and by 1802 ca. $5500 \mathrm{~m}^{3}$ of wood per year (Cancrinus 1767; Laurop 1802). The ironworks purchased the wood from neighboring state forests and coordinated the charcoal makers. The iron ore was mostly obtained from the Hohenkirchen mining district, which is situated $18 \mathrm{~km}$ southwest of Veckerhagen (Fig. 1). From the early 19th century onwards, the importance of charcoal for iron smelting decreased, since coal-derived coke was increasingly available (Cancrinus 1767; Laurop 1802; Wick 1910; Lotze 1997).

\section{Kellerwald-Edersee National Park}

The importance of charcoal making in the area of the current Kellerwald-Edersee National Park is highlighted by a forest decree issued by the Prince of Waldeck in 1741 (Fürst von Waldeck-Pyrmont 1741). This decree emphasizes the increasing demand from mines, smelting works and hammer mills for charcoal, fuelwood, and construction timber, and provides detailed instructions for protecting the forest resources from depletion. In particular, the forest administration was instructed to supervise the cutting of wood for charcoal making very strictly. Trees that were suitable for timber production or technical purposes had to be excluded from charcoal production. Besides charcoal, also wood ash was made in the area, the relics of ash production sites can be found in the forest (Sippel 2009). 


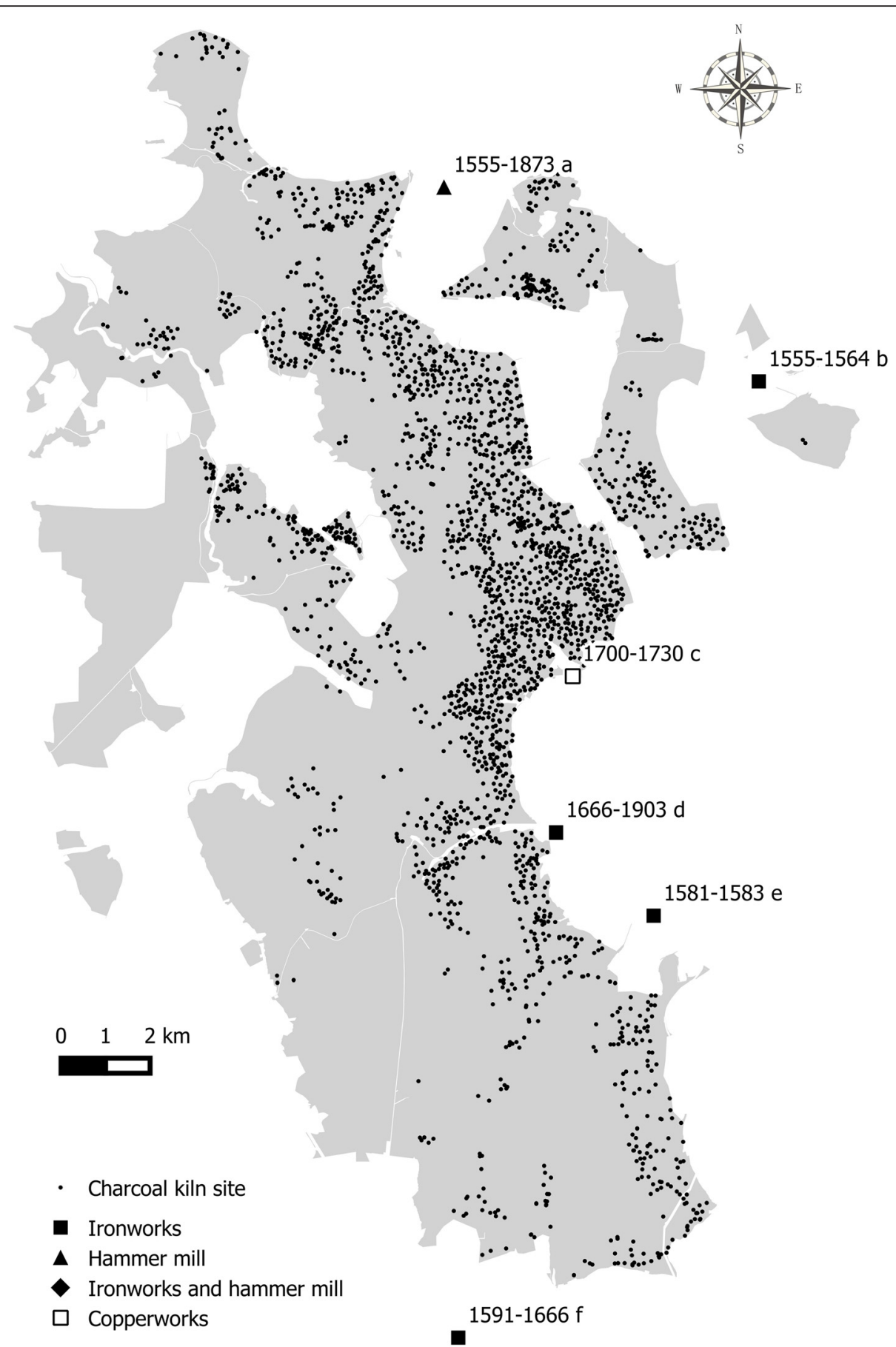

Fig. 4 The study area Reinhardswald with the location of the mapped charcoal kiln sites and historical industrial sites. a: Lippoldsberg, b: Heisebeck, c: Olbetal, d: Veckerhagen, e: Vaake, f: Knickhagen

In Waldeck, the early industrial iron production had its heyday between the 16th and 18th century. During this time, a multitude of mostly small ironworks and hammer mills (e.g. Vornhagen 1540-1710, Kleinern 1657-1870, Gellershausen 1658-1664) were in operation in the vicinity of the current Kellerwald-Edersee National Park (Fig. 3) (Mannel 1908; Schäfer 1977). The most important complex of ironworks and associated hammer mills was located in the valleys of the rivers Eder and Werbe, ca. $2 \mathrm{~km}$ north of the Kellerwald-Edersee National Park. The first written record of this proto-industrial area is from 1623. The central ironworks was the Bericher Faktorei (smelting works and associated hammer mills), which had its peak period in the early 18 th century. The iron ore was 
purchased from the Adorf mining district, which is situated $35 \mathrm{~km}$ northwest of the ironworks (Fig. 1). Charcoal and fuelwood were mostly obtained from the adjacent state-owned forests. Between the 17th and 19th century the charcoal and fuel wood supply of the Bericher Faktorei had been strictly regulated by the governmental forest administration. Various measures were aimed at preventing both forest over-exploitation and the wasting of wood. The price of the wood was regulated, and wood delivery to the ironworks and their charcoal makers was made dependent on the available felling volume. There were certain situations in which the ironwork in Berich had to cease its operations due to fuel shortage, or was compelled to purchase charcoal from other regions (Curtze 1850; Mannel 1908; Schäfer 1977). Between 1750 and 1806, the annual wood consumption of the Bericher Faktorei amounted to a mean of $7500 \mathrm{~m}^{3}$. This factory had faded in significance by 1833 and subsequently closed down in 1875 (Mannel 1908).

In the territory of the former Landgraviate of HesseKassel next to the village of Frankenau, $2 \mathrm{~km}$ south of the Kellerwald-Edersee National Park, an ironworks operated from 1576 to 1663 . Charcoal and fuelwood were, however, presumably obtained from the Itter estate (Boucsein 2009). The ironworks and hammer mills of the Haina Hospital, ca. $12 \mathrm{~km}$ southeast of the Kellerwald-Edersee National Park, had been operating between the early 16th and the 19th century and were able to gain the charcoal and fuelwood supply from the surrounding woods (Wick 1910; Friedrich 1990; Zarges 1999; Boucsein 2009). In the village of Thalitter in the Itter estate, $8 \mathrm{~km}$ northwest of the Kellerwald-Edersee National Park, a copperworks was in operation from 1712 to 1868 . This factory also consumed large quantities of charcoal and fuelwood (Cancrinus 1767; Tasche 1849; Paul 1939). In those parts of the Kellerwald-Edersee National Park which belonged to the Itter estate, charcoal making had its peak in the 19th century (Zarges 1999).

\section{Charcoal kiln site distribution \\ Digital terrain model (DTM) and landscape attributes}

For the systematic mapping of charcoal kiln sites, we used a digital terrain model (DTM), which was derived from state-wide airborne laser scanning (ALS) data by the Hessian State Office of Land Management and Geoinformation (HVBG). The ALS data were recorded between 2009 and 2012 and the applied DTM provided a spatial resolution of $1 \mathrm{~m}^{2}$ (Doneus et al. 2008; Gertloff 2011; Risbøl et al. 2013; HVBG 2015). Two different hillshade images were produced from the DTM, which varied with regard to the lighting conditions. This enabled us to visually identify charcoal kiln sites with great accuracy (Fig. 2).
For each kiln site data point, we determined the parameter values of four landscape attributes from digital forest inventory maps ("tree species composition"), forest site survey maps ("water supply status", "nutrient supply status"), and soil maps ("soil complex classes"). Soil complex classes have been mapped at a scale of 1:50,000 (HNUG 2002), the scale of forest inventory maps was 1:50,000 and that of the site survey maps was 1:25,000 (HMULF 2002). The three landscape attributes "altitude", "exposition" and "inclination" were derived from the DTM. Since the foundations of charcoal kilns are always small plateaus, the parameter values of the attributes "exposition" and "inclination" were calculated as mean values of 15 -m-wide rings around 15 -m-wide buffer circles at the kiln site data points. The landscape attributes mentioned above were also determined for the total areas of each studied forest landscape. All geospatial analyses were performed using GRASS GIS 7 (GRASS Development Team 2015) and QGIS 2.11 software (QGIS Development Team 2015).

\section{Comparison of DTM-based surveys and field inventories of charcoal kiln sites}

Georeferenced data from field inventories of charcoal kiln sites in the northern Reinhardswald (Koch 1990; Stephan 2010) enabled us to compare DTM-derived information on charcoal kiln sites with data collected in the traditional way and without the use of GPS (Ludemann 2012). Within an area of 847 ha, we identified 414 charcoal kiln sites by interpreting the DTM, while merely 328 of these (79\%) were located during the field surveys. Apart from the greater effort of field inventories, the positional accuracy of the DTM-derived point data was much higher. Divergences of more than $50 \mathrm{~m}$ were not unusual between the field survey points and the actual kiln site locations.

\section{Statistical analysis}

All statistical analyses were performed by using the $\mathrm{R}$ software version 3.2.2 (R Development Core Team 2015) with the "vegan" package (Oksanen et al. 2012) and the "cluster" package (Maechler et al. 2015). Significance of statistical tests was noted as follows: ${ }^{* * *}=p \leq 0.001 ;{ }^{* *}=p \leq 0.01$; $*=p \leq 0.05$; n.s. $=p>0.05$.

\section{Univariate analysis}

Using a chi-square test, we checked whether the frequency distributions of charcoal kiln sites with respect to the levels of the various landscape attributes were proportional to the distribution of these landscape attributes in the total study areas. We applied the likelihood ratio test (cf. Gould et al. 2006): 


$$
G^{2}=2 \sum_{1}^{c} n_{i} \log \left(n_{i} / \hat{\mu}_{l}\right) \quad \text { with } i=1(1) \mathrm{c}
$$

$G^{2}$ is $\chi^{2}$-distributed with $c$-1 degrees of of freedom, where $n$ is the total number of charcoal kiln sites, $n_{i}$ the observed charcoal kiln sites in the $i$-th factor level, and $\hat{\mu}_{l}=p_{i} \times n$ the theoretical values of the total area in this level.

\section{Multivariate and cluster analysis}

In order to better specify the multivariate structure in the data of the charcoal kiln sites, we conducted a principal component analysis (PCA; cf. Venables and Ripley 2002). For this purpose, the nominal variables "water supply status", "nutrient supply status", "soil complex classes", "exposition", and "main tree species" were transformed into dichotomous variables with regard to the respective factor levels. Only dichotomous variables were used for further analysis. In order to fit the dichotomous variables of both studied forest areas onto the PCA plot, we used the function "envfit" provided by the "vegan" package in R (Oksanen et al. 2012). A biplot was created, which allowed for the analysis of the correlation between the different variables and both forest areas.

\section{Results}

\section{Charcoal kiln site distribution}

General features of charcoal kiln site distribution

In the Reinhardswald, we registered a total number of 2626 charcoal kiln sites, which equates to a frequency of one charcoal kiln site per 7.7 ha. For the KellerwaldEdersee National Park we found 1308 charcoal kiln sites, with a slightly higher frequency of one charcoal kiln site per 4.3 ha. In both study areas, the number of charcoal kiln sites per hectare ranges between 0 and 4. Generally, the spatial distribution of the charcoal kiln sites is irregular and different between both forest areas. In the Reinhardswald, there is a concentration in the north and the middle of the eastern part of the area, while in the western part charcoal kiln sites are completely absent in many places (Fig. 4). In the Kellerwald-Edersee National Park, the distribution of charcoal kiln sites is much more even. Only few parts of the National Park exhibit no evidence of charcoal kiln sites (Fig. 3).

Patterns of charcoal kiln sites distribution in the study areas To determine possible differences in the distribution of charcoal kiln sites between both study areas and their dependence on particular landscape attributes, a PCA was conducted. The PCA (Fig. 5) clearly showed that the

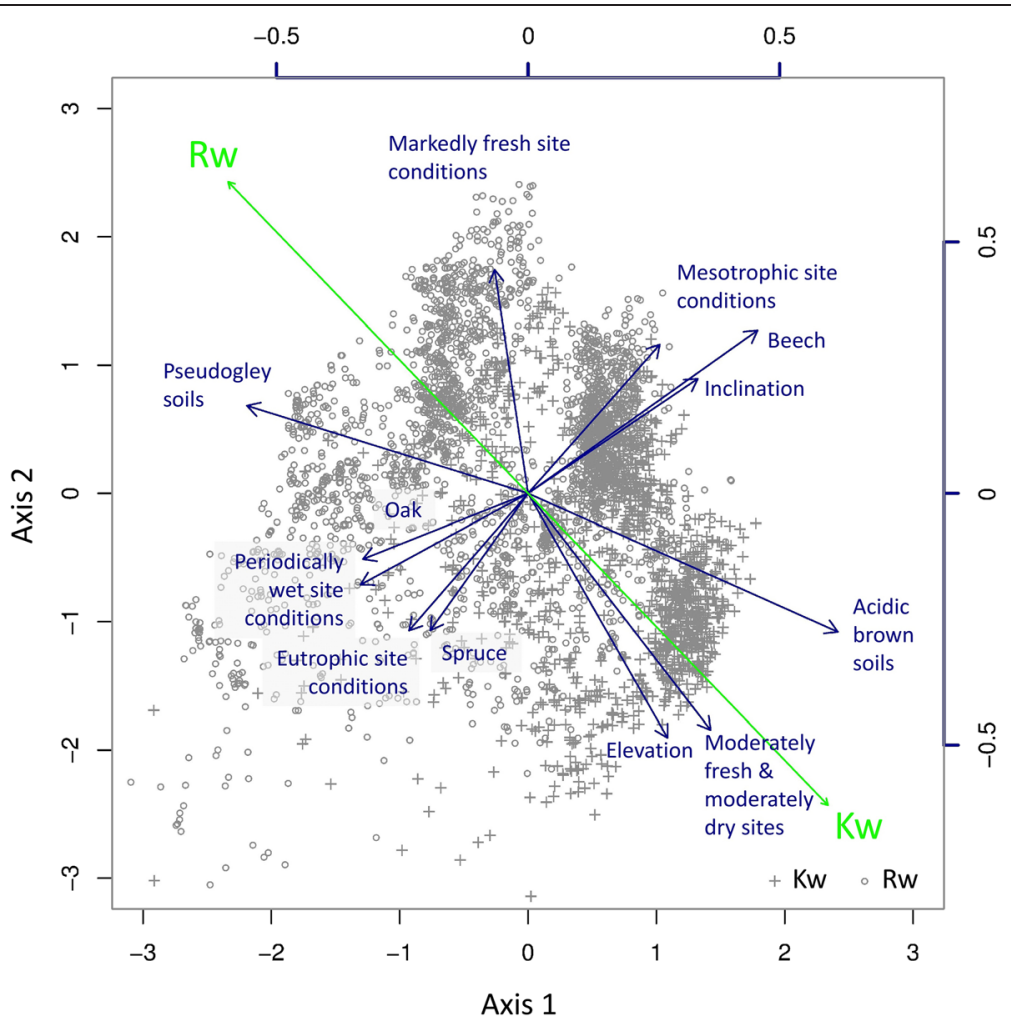

Fig. 5 PCA/biplot of the charcoal kiln sites data. Matrix: 3934 charcoal kiln sites. Reinhardswald (Rw): 2626 kiln sites, Kellerwald-Edersee National Park (Kw): 1308 kiln sites. Axis 1: eigenvalue $=1.67$, axis 2: eigenvalue $=1.51$, combined $R^{2}$ of axes 1 and $2=0.19$ 
majority of the charcoal kiln sites were located on the right side of axis 1 . The crucial landscape attributes were the occurrence of beech, steeper slopes, and mesotrophic site conditions. Of minor importance were the abundance of oaks and spruce, as well as periodically wet and eutrophic site conditions. Only a few charcoal kiln sites in the total data set featured these landscape attributes. On axis 2 of the ordination, a separation occurred according to the area-specific characteristics of the charcoal kiln sites in both studied regions. With regard to the Kellerwald-Edersee National Park (Kw), the charcoal kiln sites tended to occur in higher elevations and on moderately fresh as well as moderately dry sites. The occurrence of charcoal kiln sites on acidic brown soils was less pronounced. When looking at the Reinhardswald $(\mathrm{Rw})$, the charcoal kiln sites showed a tendency to occur on sites with markedly fresh conditions, but they can also be found on pseudogley soils, which are of minor significance in the KellerwaldEdersee National Park.

\section{Landscape attributes: whole study areas vs. charcoal kiln sites}

In the following section, we contrast the landscape attributes found throughout the whole of the two study areas with the landscape attributes which were to be found only at the charcoal kiln sites. For this purpose, classes and levels were compiled and the respective percentages for the total areas and the kiln sites were compared (Table 1). This comparison shows that the percentage distribution of the charcoal kiln sites with respect to all tested landscape attributes is statistically significantly different from the distribution of landscape attributes throughout the whole of the study areas.

Firstly, the forest site survey data were evaluated in order to compare the average water and nutrient supply status of the whole study areas with the water and nutrient supply status at the charcoal kiln sites. Concerning the water supply status, we found significant differences when conducting these comparisons. In the Reinhardswald, most of the charcoal kiln sites are located both on fresh $(57 \%)$ and markedly fresh (26\%) soils, while fresh (49 \%) and markedly fresh (14\%) soils are much less common throughout the whole Reinhardswald area. On the contrary, periodically moist soils, which occupy $23 \%$ of the whole Reinhardswald area, are significantly underrepresented at charcoal kiln sites with a portion of $6 \%$. Comparable patterns were found in the KellerwaldEdersee National Park, where fresh (30\%) and particularly fresh $(13 \%)$ soils are significantly over-represented at charcoal kiln sites. Throughout the whole National Park area, these water supply statuses account for 18 and $6 \%$, respectively. Moderately fresh (42\%) and moderately dry (11\%) soils are also relatively common at charcoal kiln sites. However, compared to the whole area of the National Park, where these water supply statuses account for 47 and $25 \%$, they are under-represented at charcoal kiln sites.

There are also significant differences in the nutrient supply status. These differences are, however, small in relation to the differences found in the other landscape attributes and are not stressed here. Both in the Reinhardswald and in the Kellerwald-Edersee National Park, $93 \%$ of the forest sites are classified as mesotrophic. These portions are very close to the values found at the charcoal kiln sites, which amount to $96 \%$ in the Reinhardswald and $93 \%$ in the Kellerwald-Edersee National Park.

In the Reinhardswald, we found a significant difference regarding the distribution of soil complex classes when comparing the whole study area and the charcoal kiln sites. The majority (52\%) of charcoal kiln sites are to be found on acidic brown soils, while this soil complex class covers merely $34 \%$ of the whole study area. Pseudogleys, however, predominate on $55 \%$ of the Reinhardswald area, while they are under-represented at the charcoal kiln sites (38\%). In the Kellerwald-Edersee National Park, most charcoal kiln sites are also linked to acidic brown soils (79 \%) and pseudogleys (13\%). This pattern, however, corresponds more closely to the distribution of these two soil complex classes in the whole study area (88 and $7 \%$ ).

With regard to the landscape attribute altitude, we found differences in frequency when comparing the whole study areas with the charcoal kiln sites. While in the Reinhardswald charcoal kiln sites frequently occur below 300 m a.s.l., in the Kellerwald-Edersee National Park they can be found disproportionately frequently above $500 \mathrm{~m}$ a.s.l.

Concerning the exposition in both forests areas there are differences between the distribution at the charcoal kiln sites and in the whole study area. In the Reinhardswald NE, $\mathrm{E}$ and SE exposure is over-represented. In the KellerwaldEdersee National Park N, NE and E aspect is overrepresented.

Significant differences could also be detected concerning the landscape attribute inclination in the Reinhardswald. In this study area, the majority of charcoal kiln sites are situated on slopes with an inclination of $10^{\circ}-<20^{\circ}(40 \%)$ or $20^{\circ}-<30^{\circ}(9 \%)$, while such inclinations occur only on $19 \%\left(10^{\circ}-<20^{\circ}\right)$ and $5 \%\left(20^{\circ}-<30^{\circ}\right)$ of the whole Reinhardswald area. Nearly flat terrain with an inclination of less than $5^{\circ}$ reaches a proportion of $40 \%$ in the whole study area, but is distinctly under-represented at charcoal kiln sites (15\%). In the Kellerwald-Edersee National Park, however, the differences in inclination between the whole study area and the charcoal kiln sites are less significant. Here, it can be seen that charcoal kiln sites are most 
Table 1 Characteristics of the landscape attributes in the Reinhardswald and the Kellerwald-Edersee National Park, given for the whole study areas and the charcoal kiln sites, respectively

\begin{tabular}{|c|c|c|c|c|c|}
\hline & \multicolumn{2}{|c|}{ Reinhardswald } & \multicolumn{2}{|c|}{ Kellerwald-Edersee National Park } & \\
\hline & \multirow[t]{2}{*}{ Total area } & \multirow{2}{*}{$\begin{array}{l}\text { Kiln sites } \\
n=2576\end{array}$} & \multirow[t]{2}{*}{ Total area } & \multicolumn{2}{|l|}{ Kiln sites } \\
\hline Water supply status & & & & $n=1297$ & \\
\hline Dry & 0.1 & 0 & 1.8 & 0 & $\%$ \\
\hline Moderately dry & 0.6 & 0.4 & 24.6 & 11.5 & $\%$ \\
\hline Moderately fresh & 9.9 & 8.9 & 47.4 & 42.3 & $\%$ \\
\hline Fresh & 48.7 & 56.8 & 18.4 & 29.8 & $\%$ \\
\hline Markedly fresh & 14.2 & 25.7 & 5.7 & 12.9 & $\%$ \\
\hline Periodically moist & 22.7 & 6.4 & 0.1 & 0.2 & $\%$ \\
\hline Moist & 1.0 & 1.2 & 1.7 & 3.2 & $\%$ \\
\hline Moderately wet & 0.2 & 0.2 & 0.3 & 0.2 & $\%$ \\
\hline \multirow[t]{2}{*}{ Wet } & 2.4 & 0.3 & 0 & 0 & $\%$ \\
\hline & \multicolumn{2}{|c|}{$p<0.001^{* * *}$} & \multicolumn{2}{|c|}{$p<0.001^{* * *}$} & \\
\hline Nutrient supply status & & $n=2602$ & & $n=1297$ & \\
\hline Oligotrophic & 1.7 & 0.2 & 0.2 & 0 & $\%$ \\
\hline Slightly mesotrophic & 3.6 & 1.2 & 0.1 & 0 & $\%$ \\
\hline Mesotrophic & 93.1 & 96.3 & 93.1 & 93.1 & $\%$ \\
\hline Distinctly mesotrophic & 0.7 & 0.8 & 4.5 & 3.6 & $\%$ \\
\hline Slightly eutrophic & 0.1 & 0 & 0.3 & 0.2 & $\%$ \\
\hline \multirow[t]{2}{*}{ Eutrophic } & 0.8 & 1.5 & 1.9 & 3.1 & $\%$ \\
\hline & \multicolumn{2}{|c|}{$p<0.001^{* * *}$} & \multicolumn{2}{|c|}{$p<0.01^{* *}$} & \\
\hline Soil complex classes & & $n=2626$ & & $n=1308$ & \\
\hline Colluvial soils & 3.1 & 6.1 & 0 & 0 & $\%$ \\
\hline Acidic brown soils & 34.1 & 51.6 & 87.6 & 79.4 & $\%$ \\
\hline Pseudogleys & 54.7 & 38.1 & 7.4 & 12.8 & $\%$ \\
\hline Stagnogleys and fen soils & 4.7 & 1.2 & 0 & 0 & $\%$ \\
\hline \multirow[t]{2}{*}{ Gleys } & 3.3 & 2.9 & 5.0 & 7.9 & $\%$ \\
\hline & \multicolumn{2}{|c|}{$p<0.001^{* * *}$} & \multicolumn{2}{|c|}{$p<0.001^{* * *}$} & \\
\hline Altitude & & $n=2626$ & & $n=1308$ & \\
\hline$<200 \mathrm{~m}$ & 9.6 & 14.8 & 0 & 0 & $\%$ \\
\hline$<300 \mathrm{~m}$ & 42.4 & 47.1 & 5.9 & 3.7 & $\%$ \\
\hline$<400 \mathrm{~m}$ & 41.0 & 35.8 & 32.1 & 27.2 & $\%$ \\
\hline$<500 \mathrm{~m}$ & 7.0 & 2.2 & 47.0 & 49.3 & $\%$ \\
\hline \multirow[t]{2}{*}{$>500 \mathrm{~m}$} & 0 & 0 & 15.1 & 19.8 & $\%$ \\
\hline & \multicolumn{2}{|c|}{$p<0.001^{* * *}$} & \multicolumn{2}{|c|}{$p<0.01^{* *}$} & \\
\hline Exposition & & $n=2626$ & & $n=1308$ & \\
\hline E & 12.3 & 17.1 & 13.5 & 15.6 & $\%$ \\
\hline$N E$ & 13.6 & 20.1 & 13.4 & 17.5 & $\%$ \\
\hline$N$ & 12.4 & 12.0 & 13.4 & 17.1 & $\%$ \\
\hline NW & 11.6 & 7.1 & 15.3 & 15.5 & $\%$ \\
\hline W & 15.1 & 8.4 & 11.6 & 9.1 & $\%$ \\
\hline SW & 15.1 & 12.5 & 8.6 & 5.5 & $\%$ \\
\hline S & 10.0 & 10.1 & 10.5 & 7.8 & $\%$ \\
\hline SE & 9.8 & 12.7 & 13.3 & 11.9 & $\%$ \\
\hline
\end{tabular}


Table 1 Characteristics of the landscape attributes in the Reinhardswald and the Kellerwald-Edersee National Park, given for the whole study areas and the charcoal kiln sites, respectively (Continued)

\begin{tabular}{|c|c|c|c|c|c|}
\hline & \multicolumn{2}{|c|}{ Reinhardswald } & \multicolumn{2}{|c|}{ Kellerwald-Edersee National Park } & \\
\hline & Total area & $\overline{\text { Kiln sites }}$ & Total area & Kiln sites & \\
\hline & \multicolumn{2}{|c|}{$p<0.001^{* * *}$} & \multicolumn{2}{|c|}{$p<0.001^{* * *}$} & \\
\hline Inclination & & $n=2626$ & & $n=1308$ & \\
\hline$<5^{\circ}$ & 40.5 & 14.7 & 11.1 & 9.2 & $\%$ \\
\hline$<10^{\circ}$ & 33.2 & 34.7 & 20.2 & 22.6 & $\%$ \\
\hline$<20^{\circ}$ & 19.3 & 40.4 & 37.5 & 48.5 & $\%$ \\
\hline$<30^{\circ}$ & 5.4 & 8.6 & 24.6 & 17.2 & $\%$ \\
\hline$<40^{\circ}$ & 1.5 & 1.4 & 6.0 & 2.4 & $\%$ \\
\hline$<50^{\circ}$ & 0.3 & 0.2 & 0.6 & 0.2 & $\%$ \\
\hline \multirow[t]{2}{*}{$\geq 50^{\circ}$} & 0 & 0 & 0.1 & 0 & $\%$ \\
\hline & \multicolumn{2}{|c|}{$p<0.001^{* * *}$} & \multicolumn{2}{|c|}{$p<0.001^{* * *}$} & \\
\hline Tree species composition & & $n=2607$ & & $n=1186$ & \\
\hline Fagus sylvatica & 39.7 & 73.2 & 66.1 & 79.1 & $\%$ \\
\hline Picea abies & 34.4 & 11.2 & 13.2 & 14.0 & $\%$ \\
\hline Quercus spp. & 17.0 & 9.7 & 6.8 & 3.7 & $\%$ \\
\hline Larix decidua & 4.2 & 2.8 & 1.9 & 1.3 & $\%$ \\
\hline Pinus sylvestris & 0.9 & 0.9 & 4.2 & 0.3 & $\%$ \\
\hline Pseudotsuga menziesii & 0.7 & 0.4 & 1.3 & 0.2 & $\%$ \\
\hline \multirow[t]{2}{*}{ other tree species and open land } & 2.9 & 1.8 & 6.4 & 1.5 & $\%$ \\
\hline & \multicolumn{2}{|c|}{$p<0.001^{* * *}$} & \multicolumn{2}{|c|}{$p<0.001^{* * *}$} & \\
\hline
\end{tabular}

frequently situated on slopes with an inclination of $5^{\circ}-<10^{\circ}(23 \%)$ or $10^{\circ}-<20^{\circ}(48 \%)$, while such inclinations occur only on $20 \%\left(5^{\circ}-<10^{\circ}\right)$ and $38 \%\left(10^{\circ}-<20^{\circ}\right)$ of the whole Kellerwald-Edersee National Park area.

With regard to the current tree species composition, both in the Reinhardswald and in the Kellerwald-Edersee National Park, beech is by far the most important tree species at the charcoal kiln sites and reaches portions of 73 and $79 \%$, respectively. In the Reinhardswald, beech is clearly over-represented at the charcoal kiln sites, while spruce (Picea abies) occurs less frequently at the kiln sites compared to the whole study area. There is less difference in the composition of tree species between the charcoal kiln sites and the entire study area in the KellerwaldEdersee National Park. Nevertheless, in this study area the percentage of beech on charcoal kiln sites (79\%) is still higher than that in the whole forest area (66\%).

\section{Discussion}

Relationships between the distribution of charcoal kiln sites and landscape attributes

By contrasting the landscape attributes of the two whole study areas with the landscape attributes which were to be found at the charcoal kiln sites, we were able to draw several conclusions about the conditions that had to be met for the construction of charcoal kiln sites in the forest.

The underlying bedrocks provide, both in the Reinhardswald (sandstone) and in the National Park Kellerwald-Edersee (clay shale and greywacke), favorable conditions for the establishment of charcoal kilns, since they enable a constant underground air flow to the kiln due to their physical properties (von Berg 1860). Differences in the spatial distribution of charcoal kiln sites, however, are correlated with the occurrence of certain soil types. It can be seen that the majority of charcoal kiln sites (91\% in the Reinhardswald and $85 \%$ in the Kellerwald-Edersee National Park) were constructed on fresh soils (fresh, moderately fresh, markedly fresh), although this proportion does not match the expected value in both study areas. In contrast, periodically moist soils in the Reinhardswald and moderately dry soils in the Kellerwald-Edersee National Park (covering about a quarter of the respective study areas) are under-represented at the charcoal kiln sites in both forest landscapes. The correlation of charcoal kiln site distribution and water supply status is reflected in the distribution of soil complex classes. In both study areas, the majority of the charcoal kiln sites are located on acidic brown soils, which are characterized by fresh conditions. Furthermore, there is a concentration of charcoal kiln sites 
at slightly inclined to moderately inclined slopes $\left(5^{\circ}-<30^{\circ}\right)$, on which $88 \%$ of the charcoal kiln sites in the Reinhardswald and $84 \%$ of the kiln sites in the Kellerwald-Edersee National Park were constructed.

From these distribution patterns, it appears that the forest officers preferentially allocated those forest stands to the wood-colliers, which were located on hillsides with fresh site conditions, good drainage, and acidic brown soils. This corresponds almost exactly to the descriptions given in the older literature regarding the preferred location of charcoal kiln sites. Already von Carlowitz (1732) pointed out that wet and swampy areas should be avoided. This view is also represented by Klein (1836), Dietrich (1847) and von Berg (1860). According to von Berg (1860), clay soils with an admixture of top soil represent the best ground for charcoal kilns. Acidic brown soils have these characteristics. To facilitate the delivery of wood and the transportation of charcoal, and to prevent extensive earthworks, the labor-intensive construction of charcoal kiln sites on very steep slopes should be avoided (Klein 1836; von Berg 1860).

The fresh and mesotrophic hillside locations, on which charcoal kiln sites in the Reinhardswald and the Kellerwald-Edersee National Park are concentrated, offer optimal growing conditions for beech (Ellenberg and Leuschner 2010), the preferred wood for charcoal making in both study areas (see the third section of the discussion). On these soils, the growth performance and regeneration capacity of beech is significantly better than on periodically moist or moderately dry soils (Leuschner 1997). There is evidence that stands at periodically moist soils on the plateau of the Reinhardswald were widely cleared and sparsely stocked in the second half of the 18th century (Laurop 1802; Chwalczyk 1988). This can be attributed to the fact that the wood was easy to reach and to remove. In addition, these plateau areas were densely covered with grass due to woodland pasture. Along with browsing by cattle and deer, a dense grass cover is an obstacle to tree regeneration (Laurop 1802; Mitchell and Kirby 1990; Coll et al. 2003).

On the moderately dry soils in the Kellerwald-Edersee National Park, the growth performance of beech is also limited. Due, in particular, to repeated harvesting at sunexposed southern slopes, oaks and hornbeam (Carpinus betulus) were promoted here, while beech dominates on moderately fresh and fresh soils and usually forms pure stands (cf. Ellenberg and Leuschner 2010). A similar anthropogenic influenced, site-specific forest development is described by Speier (1994) for the more westerly situated Rothaargebirge mountain range.

\section{Relationships between the distribution of charcoal kiln sites and the main charcoal consumers}

Between the 16th and 18th century (and even before), the establishment of copper- and iron-works was closely related to the supply of wood types suitable for charcoal making and, to a lesser extent, on the occurrence of ore bearing rock, which often had to be transported over long distances to the works (Curtze 1850; Seidensticker 1896; Wick 1910; Rippel 1958; Schäfer 1977; Boucsein 2009). Schott (1997) emphasizes that proto-industrial iron smelting, which was based on the utilization of fuelwood or charcoal, inevitably had to be decentrally organized, its development being dependent on the availability of fuelwood supply. This point of view is supported by Oelke (1974), who investigated the development of the iron industry in the eastern Harz Mountains (Central Germany). For these reasons, ore smelting always took place in the vicinity of large forest areas. It can therefore be assumed that, at the time of the smelting works' establishment, the decision-makers estimated that there was sufficient availability of wood resources in the surrounding area in the medium- to long-term. Moreover, charcoal burners could utilize forest stands at poorly accessible hillside locations, since it is easier to transport charcoal than wood (Jacobi 1912; Bonnemann 1984; Zarges 1999).

With regard to the Reinhardswald, the late-16th and 17 th century forest decrees explicitly point out that there was a huge amount of lying wood. However, a report from 1617 mentions an overexploitation of the Reinhardswald due to charcoal making (Wick 1910). This contradiction can be solved by a spatial differentiation into easily accessible, heavily used stands on the one hand and poorly accessible, well conserved stands on slopes on the other (cf. Laurop 1802). For the 16th and early 17th century it has been frequently reported that charcoal burners were advised to carbonize lying wood that was hardly applicable for other purposes due to the steepness of the terrain (Wick 1910; Höfer 1947). In accordance with this, the first state-owned ironworks in the Landgraviate of Hesse-Kassel was established in the village of Vaake in 1581 to utilize a large amount of unused wood in the surrounding forests (Wick 1910).

As argued in the following section, the results provide strong evidence that there have been well-stocked forests in both studied woodland landscapes between the 17th and 19th century. This is especially true for those sites that were unsuitable for wood exploitation and pasture due to poor accessibility, a lack of paths, and pronounced steepness of the terrain (cf. Jacobi 1912). It is precisely these areas that provided optimal growing and regeneration conditions for beech due to their acidic brown soils and balanced water budget. In the Reinhardswald, such sites are most frequently located on slopes of the Weser valley at altitudes below 300 m a.s.l. In the Kellerwald-Edersee National Park they are concentrated at altitudes greater than $400 \mathrm{~m}$ a.s.l. Here, charcoal production was able to occupy a niche that could not be filled by other types of forest use. This created 
the conditions for the establishment of smelting works and hammer mills that were desired by the sovereign.

In the area of the Kellerwald-Edersee National Park, the Bericher Faktorei was established in the 17th century, since the forests in the wider surroundings were wellstocked. Different measures were aimed at preventing both forest over-exploitation and the wasting of wood (see the above section on the regional setting of the study areas). As Mannel (1908) states, the fuel supply of the ironworks enjoyed special attention, "since people had the forest every day before their eyes, they saw with their own eyes, how it was reduced at increased operating pressure, while the decrease of ironstone was withdrawn from observation." Additionally, and this is a very important point raised by Hammersley (1973), most of the proto-industrial ironmasters wanted to protect their investment and maintain their profits, and that needed fuel security for the future as well as the present.

\section{Woodland conditions and tree species composition at the time of charcoal production}

On those types of sites where charcoal kilns had been primarily constructed, beech is today the main tree species, with cover of over $70 \%$ in both study areas. It can be assumed that beech was also the dominant tree species at the time of the charcoal kilns' construction. This assumption is supported by historical forest inventory maps, such as the "Master Map of the Reinhardswald" from 1827 (Marburg State Archive, Map P II 2079). Since a charcoal kiln had to be set up with wood types of comparable consistency, hard beech wood was not allowed to be carbonized in combination with soft conifer, birch or willow wood (von Berg 1860). In both study areas, conifers (especially spruce) did not reach significant proportions until ca. 1850, and have been increasingly cultivated on degraded land since then (Mackeldey 1971; Zarges 1999). Conifer wood, therefore, played no role for charcoal making in both the studied forest landscapes. Although it is documented that tree species like oaks, hornbeam, alder or birches have been used for charcoal production (Wick 1910; Schwedes 1983), it is evident that beech was preferred in both the Reinhardswald and the area of the Kellerwald-Edersee National Park (Fürst von Waldeck-Pyrmont 1741; Wick 1910).

As von Berg (1860) emphasizes, charcoal made from beech can be used advantageously for all technical industries and most metallurgical processes, particularly for the production of crude steel. The obvious preference for beech wood for charcoal making in both studied forest landscapes agrees well with anthracological findings from the Solling mountain range directly north of the Reinhardswald (Hillebrecht 1982). In other forest landscapes, though, the conditions were different. Spruce was, for instance, the main tree species for charcoal making in the Harz Mountains (Hillebrecht 1982; Knapp et al. 2015), while in the Rothaargebirge mountain range mainly beech, oaks and birches had been carbonized (Jung 1779; Speier 1994). In the Westerwald mountain range, hornbeam and beech were the target species (Heuser-Hildebrandt 2002), and in the Black Forest spruce, silver fir (Abies alba) and beech dominated the spectrum of utilized tree species (Ludemann 2010).

From the findings obtained in this study, we conclude that there have been well-stocked and beech-dominated deciduous forest stands in northern Hesse before 1800, particularly at poorly accessible hillside locations in state-owned forests. However, these stands were in many places accompanied by areas of overexploited woodland. With regard to the Reinhardswald, Chwalczyk (2000) stated that the local stands were better stocked than other Hessian forest areas, despite the century-long tradition of wood pasture and of a partial forest devastation in the Seven Years' War (1756-1763). This was true particularly for hillside locations. Through an evaluation of archival material from the 18th century, Jäger (1951) argues convincingly for the existence of well-stocked beech stands on the poorly accessible slopes of the Weser valley. There was so much wood, that not only the fuelwood depot in the capital city of Kassel could be supplied, but also the foreign market. This assessment is not only supported by Schenk (1996) and the results of the present study, but also by contemporary forest descriptions made by Laurop (1802).

For the area of the Kellerwald-Edersee National Park, the small-scale map "Waldeck Comitatus" (Blaeu 1635) shows a forest symbol only for higher elevations, where, according to our results, charcoal kiln sites occur with greater densities. Although we do not expect that the remaining lower areas were actually unwooded, we see this as an indication of closed and connected woodland at the higher elevations. These considerations are in line with Jung (1779), who described well-stocked, beechdominated 18th century forests in the Rothaargebirge, a mountain range west of our study areas, which was also a center of charcoal production.

For the governments of the different Hessian territories, utilizing the large stocks of beech wood through the establishment of ironworks and hammer mills was an obvious step. However, with the introduction of coal-derived coke from the early 19th century onwards, both woodland areas lost their outstanding importance as fuel suppliers and the iron industry was relocated to the flourishing coal fields, particularly to the Rhineland and to Westphalia (Mannel 1908; Wick 1910).

\section{Conclusions}

We found that charcoal kiln sites were preferably established on hillside locations that, due to their acidic brown 
soils and sufficient water supply, provided optimal growing and regeneration conditions for beech. These results are in line with instructions for the selection of appropriate kiln site locations found in literature from the 18th to the 19th century. From our findings, we conclude that there have been well-stocked, beechdominated deciduous forest stands in northern Hesse before 1800 , particularly at poorly accessible hillside locations. The governments of the different Hessian territories utilized the large stocks of beech wood through the establishment of ironworks and hammer mills.

Our argumentation is in line with Schenk (1996) and Radkau (2006), who underlined that Hessian forests were not overexploited in all areas in the 18th century. Frequently repeated complaints about "wood shortage" seem to be more a political instrument than reality, since they were first and foremost aimed at enforcing the financial, administrative, and political goals of the government (Schenk 1996). This insight was not only obtained in Hesse (Schenk 1996; Reinhardt 1999; Radkau 2006), but all over Europe (von Berg 1844; Warde 2006). Consequently, a differentiated assessment of woodland conditions in proto-industrial times is strictly advised, even if contemporary sources draw a dark picture of the historic situation.

\section{Competing interests}

The authors declare that they have no competing interests.

\section{Authors' contributions}

MS and AM planned and conducted the study and wrote the majority of the manuscript. ES and FE executed the GIS and statistical analyses. WF has contributed knowledge about the Kellerwald-Edersee National Park. All authors read and approved the final manuscript.

\section{Acknowledgements}

We thank Achim Frede (Kellerwald-Edersee National Park, Bad Wildungen), Peter Meyer (Northwest German Forest Research Institute, Göttingen), Hermann-Josef Rapp (retired forester in the Reinhardswald, Reinhardshagen), and Klaus Sippel (Hessian State Conservation Office, Marburg) for helpful discussions and their comments on an earlier version of the manuscript. We are grateful to Robert Larkin for proofreading. The authors are also indebted to two anonymous reviewers for suggestions that have greatly improved the paper.

\section{Author details}

${ }^{1}$ Northwest German Forest Research Institute, Department A (Forest Growth), Grätzelstraße 2, D-37079 Göttingen, Germany. ${ }^{2}$ Kellerwald-Edersee National Park, Laustraße 8, D-34537 Bad Wildungen, Germany.

Received: 7 January 2016 Accepted: 7 March 2016

Published online: 19 March 2016

\section{References}

Armstrong L (1978) Woodcolliers and charcoal burning. Coach Publishing House, Horsham

BfN (2010) Karte der Potentiellen Natürlichen Vegetation Deutschlands. Bundesamt für Naturschutz (BfN), Bonn

Blaeu W (1635) Waldeck Comitatus. Willem Blaeu, Amsterdam

Bofinger J, Hesse R (2011) As far as the laser can reach... Laminar analysis of LiDAR detected structures as a powerful instrument for archaeological heritage management in Baden-Württemberg, Germany. In: Cowley DC (ed)
Remote sensing for archaeological heritage management. Europae Archaeologia Consilium (EAC), Bruxelles, pp 161-171

Bonhôte J, Davasse B, Dubois C, Izard V, Métailié J-P (2002) Charcoal kilns and environmental history in the eastern Pyrenees (France). A methodological approach. In: BAR International Series 1063. Archaeopress, Oxford pp 219-228

Bonnemann A (1984) Der Reinhardswald. Verlag der Weserbuchhandlung, Hann. Münden

Born M (1961) Frühgeschichtliche Flurrelikte in den deutschen Mittelgebirgen. Geogr Ann 43:17-25. doi:10.2307/520229

Boucsein H (2009) Geschichte der Wälder und Forsten in Oberhessen: Eine integrierte Kulturgeschichte des hessischen Forstwesens. Burgwald-Verlag, Cölbe-Schönstadt

Cancrinus FL (1767) Beschreibung der vorzüglichsten Bergwerke in Hessen, in dem Waldekkischen, an dem Haarz, in dem Mansfeldischen, in Chursachsen, und in dem Saalfeldischen. Andreäische Buchhandlung, Frankfurth an dem Main.

Chwalczyk C (1988) Der Reinhardswald. In: Hessische Landesforstverwaltung (ed) Wald in Hessen. Gestern, heute und morgen. Hessische Landesforstverwaltung, Wiesbaden, pp 1-218

Chwalczyk C (2000) Merkwürdigkeiten zum Reinhardswald. In: Hessische Landesforstverwaltung (ed) Werden und Wandel - Hessens Forstwirtschaft auf dem Weg in das 3. Jahrtausend. Hessische Landesforstverwaltung, Wiesbaden, pp 69-82

Coll L, Balandier P, Picon-Cochard C, Prévosto B, Curt T (2003) Competition for water between beech seedlings and surrounding vegetation in different light and vegetation composition conditions. Ann For Sci 60:593-600. doi:10.1051/forest:2003051

Collin G, Wetzel W (2004) Zur Geschichte der Eisengewinnung mit Holzkohle und Steinkohlenkoks. NTM NS 12:65-79. doi:10.1007/s00048-004-0189-8

Curtze L (1850) Geschichte und Beschreibung des Fürstenthums Waldeck. Speyer'sche Buchhandlung, Arolsen

Deforce K, Boeren I, Adriaenssens S, Bastiaens J, De Keersmaeker L, Haneca K, Tys D, Vandekerkhove K (2013) Selective woodland exploitation for charcoal production. A detailed analysis of charcoal kiln remains (ca. 1300-1900 AD) from Zoersel (northern Belgium). J Archaeol Sci 40:681-689. doi:10.1016/j.jas. 2012.07.009

Demandt KE (1972) Geschichte des Landes Hessen, 2nd edn. Bärenreiter, Kassel

Dietrich V (1847) Das Ganze der Verkohlung in stehenden Meilern oder die sogenannte italienische Köhlerei. Verlag von Jos. A. Kienreich, Graz

Doneus M, Briese C, Fera M, Janner M (2008) Archaeological prospection of forested areas using full-waveform airborne laser scanning. J Archaeol Sci 35: 882-893. doi:10.1016/j.jas.2007.06.013

Ellenberg H, Leuschner C (2010) Vegetation Mitteleuropas mit den Alpen in ökologischer, dynamischer und historischer Sicht, 6th edn. Ulmer, Stuttgart

Friedrich A (1990) Das Berg- und Hüttenwesen des Hospitals Haina vom 16. bis 19. Jahrhundert. Geschbl f Waldeck 78:25-39

Fürst von Waldeck-Pyrmont CAF (1741) Fürstlich-Waldeckische Forst- und Jagdoder Weidewercks-Ordnung. Christoph Konert, Mengeringhausen

Gertloff K-H (2011) Detektion von Bodendenkmälern im Wald mit einem hochauflösenden Geländemodell aus Laserscannerdaten. zfv 136:86-92

Gould W, Pitblado J, Sribney W (2006) Maximum likelihood estimation with Stata, 3rd edn. Stata press, College Station

GRASS Development Team (2015) Geographic Resources Analysis Support System (GRASS). Open Source Geospatial Foundation Project, https://grass. osgeo.org/grass7/. Accessed 15 Mar 2016

Hammersley G (1973) The charcoal iron industry and its fuel, 1540-1750. Econ Hist Rev 26:593-613. doi:10.2307/2593700

Henne R (1997) Die Gemarkungen von Gewissenruh und Gottstreu - Flurorte und angrenzende Waldorte. In: Gemeinde Oberweser (ed) Waldenserdörfer Gottstreu und Gewissenruh: Beiträge zur Orts- und Heimatgeschichte und zum Dorfleben 1722-1997. Gemeindevorstand der Gemeinde Oberweser, Oberweser, pp 199-252

Hesse R (2013) The changing picture of archaeological landscapes: lidar prospection over very large areas as part of a cultural heritage strategy. In: Opitz RS, Cowley DC (eds) Interpreting archaeological topography. 3D data, visualisation and observation. Oxbow Books, Oxford, pp 171-183

Heuser-Hildebrandt B (2002) Untersuchungen zur Kulturlandschaftsentwicklung anhand von Holzkohlenspektren historischer Meilerplätze. Archiv für hessische Geschichte 60:307-332

Hillebrecht M-L (1982) Die Relikte der Holzkohlewirtschaft als Indikatoren für Waldnutzung und Waldentwicklung: Untersuchungen an Beispielen aus Südniedersachsen. Gött Geogr Abh 79:1-157 
HMULF (2002) Hessische Anweisung für Forsteinrichtungsarbeiten (HAFEA). Hessisches Ministerium für Umwelt, Landwirtschaft und Forsten (HMULF), Wiesbaden

HNUG (2002) Erläuterungen zur Bodenkarte von Hessen 1:50.000. Hessisches Landesamt für Umwelt und Geologie (HNUG), Wiesbaden

Höfer R (1947) Reviergeschichte des Forstamtes Gahrenberg im Reinhardswald: insbesondere seit 1750. Georg-August-Universität Göttingen, Göttingen

Höhle H (1929) Die untergegangenen Ortschaften oder Die Wüstungen in Waldeck. Wilh. Bings Buchdruckerei, Corbach

HLBG (2015) Produktkatalog, Heft 4, Digitale Geobasisdaten. Hessisches Landesamt für Bodenmanagement und Geoinformation (HLBG), Wiesbaden Jacobi HB (1912) Die Verdrängung der Laubwälder durch die Nadelwälder in Deutschland. Verlag der H. Laupp'schen Buchhandlung, Tübingen

Jäger H (1951) Die Entwicklung der Kulturlandschaft im Kreise Hofgeismar. Gött Geogr Abh 8:1-114

Jäger H (1958) Entwicklungsperioden agrarer Siedlungsgebiete im mittleren Westdeutschland seit dem frühen 13. Jahrhundert. Würzb Geogr Arb 6: $1-136$

Jung JH (1779) Beschreibung der Nassau-Siegenschen Methode Kohlen zu brennen mit physikalischen Anmerkungen begleitet. Bemerkungen der kurpfälzischen physikalisch-ökonomischen Gesellschaft, Lautern, pp 257-371

Klein F (1836) Über Verkohlung des Holzes in stehenden Meilern. Hennings und Hopf, Gotha

Klemm S, Nelle O, Grabner M, Geihofer D, Schnepp E (2005) Interdisziplinäre Untersuchungen von Kohlstätten aus Mittelalter und Neuzeit in der Eisenerzer Ramsau, Steiermark. Archaeologia Austriaca 89:269-329

Knapp H, Robin V, Kirleis W, Nelle O (2013) Woodland history in the upper Harz Mountains revealed by kiln site, soil sediment and peat charcoal analyses. Quat Int 289:88-100. doi:10.1016/j.quaint.2012.03.040

Knapp H, Nelle O, Kirleis W (2015) Charcoal usage in medieval and modern times in the Harz Mountains Area, Central Germany: Wood selection and fast overexploitation of the woodlands. Quat Int 366:51-69. doi:10.1016/j.quaint. 2015.01.053

Krause A (1972) Bestimmung von Meilerkohlen aus dem Hunsrück und ihre vegetationskundliche Aussage. Decheniana 125:249-253

Landgraf zu Hessen M (1593) Holtzordnung des Niedern Fürstenthumbs Hessen. Moritz Landgraf zu Hessen, Cassel.

Landgraf zu Hessen W (1629) Renovirte Holtzordnung des Niedern Fürstenthumbs Hessen. Wilhelm Landgraf zu Hessen, Cassel.

Landgraf zu Hessen C (1683) Erneuerte Forst- und Holtz Ordnung/des Fürstenthumbs Hessen Casselischen Theils. Salomon Kürßner, Cassel.

Laurop CP (1802) Briefe eines in Deutschland reisenden Forstmannes. Ein Beitrag zur Geschichte der gegenwärtigen Forstverfassung und Forstwirthschaft in Deutschland. Arntzen und Hartier, Kopenhagen

Leopold HC (1719) Abris vom Hochfürstl. Hessen-Cassel, Casse

Leuschner C (1997) Das Konzept der potentiellen natürlichen Vegetation (PNV): Schwachstellen und Entwicklungsperspektiven. Flora 192:379-391

Lotze S (1997) Veckerhagen in sieben Jahrhunderten: Beiträge zur Sozial-, Wirtschafts-, und Kunstgeschichte eines Oberweserdorfes. Die Geschichte unserer Heimat 26:11-264

Ludemann T (2003) Large-scale reconstruction of ancient forest vegetation by anthracology - a contribution from the Black Forest. Phytocoenologia 33 645-666. doi:10.1127/0340-269X/2003/0033-0645

Ludemann T (2010) Past fuel wood exploitation and natural forest vegetation in the Black Forest, the Vosges and neighbouring regions in western Central Europe. Palaeogeogr Palaeoclimatol Palaeoecol 291:154-165. doi:10.1016/j.palaeo.2009.09.013

Ludemann T (2012) Airborne laser scanning of historical wood charcoal production sites - a new tool of kiln site anthracology at the landscape level. SAGVNTVM EXTRA 13:247-252

Mackeldey W (1971) 150 Jahre Forstwirtschaft im Reinhardswald. Jahrbuch Landkreis Kassel, Kassel, pp 42-47

Maechler M, Rousseeuw P, Struyf A, Hubert M, Hornik K, Studer M, Roudier P (2015) "Finding groups in data": Cluster analysis extended. https://cran.rproject.org/web/packages/cluster/index.html. Accessed 15 Mar 2016

Mannel G (1908) Die Eisenhütten und Hämmer des Fürstentums Waldeck. Ein Beitrag zur Wirtschaftsgeschichte der deutschen Eisenindustrie. Weigel'sche Buchdruckerei, Mengeringhausen

Menzler K, Sawitzky H (2015) Biotopausstattung und Naturnähe im Nationalpark Kellerwald-Edersee. Forschungsberichte des Nationalparks Kellerwald-Edersee 2:1-184
Mitchell FJG, Kirby KJ (1990) The impact of large herbivores on the conservation of semi-natural woods in the British uplands. Forestry 63:333-353. doi:10.1093/forestry/63.4.333

Nölken W (2005) Holzkohleanalytische Untersuchungen zur Waldgeschichte der Vogesen. Dissertation an der Albert-Ludwigs-Universität, Freiburg (Breisgau)

Oelke E (1974) Die regionale Entwicklung der Eisenindustrie im östlichen Harz (bis zum Jahre 1945). Jahrbuch für Wirtschaftsgeschichte 15:319-326

Oksanen J, Blanchet FG, Kindt R, Legendre P, Minchin PR, O'Hara RB, Simpson GL, Solymos P, Stevens MHH, Wagner H (2012) vegan: Community Ecology Package. https:/cran.r-project.org/web/packages/vegan/index.html. Accessed 15 Mar 2016.

Paul C (1939) Die Geschichte des Itterschen Kupfer-Bergwerks. Bing, Korbach

Prus J (2005) Charcoal production in woodland around the blast furnace at Darwell, East Sussex. Bull Wealden Iron Res Group 25:25-37

QGIS Development Team (2015) QGIS Geographic Information System. Open Source Geospatial Foundation Project, http://qgis.osgeo.org. Accessed 15 Mar 2016

R Development Core Team (2015) R: A language and environment for statistical computing. R Foundation for Statistical Computing, Vienna, www.R-project. org. Accessed 15 Mar 2016.

Raab A, Takla M, Raab T, Nicolay A, Schneider A, Rösler H, Heußner K-U, Bönisch E (2015) Pre-industrial charcoal production in Lower Lusatia (Brandenburg, Germany): Detection and evaluation of a large charcoal-burning field by combining archaeological studies, GIS-based analyses of shaded-relief maps and dendrochronological age determination. Quat Int 367:111-122. doi:10.1016/j.quaint.2014.09.041

Radkau J (2006) Der Wald als Lebenswelt und Konfliktfeld der alten Zeit. Szenen aus hessischen Archivalien in mikro- und makroskopischer Sicht. In: Hedwig A (ed) "Weil das Holz eine köstliche Ware...". Wald und Forst zwischen Mittelalter und Moderne. Verein für Hessische Geschichte und Landeskunde, Marburg, pp 75-103

Rapp H-J (2002) Reinhardswald - eine Kulturgeschichte. Euregio-Verlag, Kassel

Reinhardt R (1999) Strukturwandel in der Eisenindustrie des Lahn-Dill-Gebietes, 1840-1914: Von der Eisenerzeugung zur reinen Eisenweiterverarbeitung in Gießereien. Inauguraldissertation an der Johann-Wolfgang-GoetheUniversität, Frankfurt (Main)

Reuter AP (1833) Die Verhältnisse der Koaks und Torfkohlen zu den Holzkohlen Allg Forst- Jagdztg 2:146-151, 153-156; 159-160

Rippel JK (1958) Die Entwicklung der Kulturlandschaft am nordwestlichen Harzrand. Niedersächsisches Amt für Landesplanung und Statistik, Hannover

Risbøl O, Bollandsås OM, Nesbakken A, Ørka HO, Næsset E, Gobakken T (2013) Interpreting cultural remains in airborne laser scanning generated digital terrain models: effects of size and shape on detection success rates. J Archaeol Sci 40:4688-4700. doi:10.1016/j.jas.2013.07.002

Rösler H, Bönisch E, Schopper F, Raab T, Raab A (2012) Pre-industrial charcoal production in southern Brandenburg and its impact on the environment. In: Kluiving SJ, Guttmann-Bond EB (eds) Landscape archaeology between art and science: From a multi- to an interdisciplinary approach. Amsterdam University Press, Amsterdam, pp 167-178

Rüstmeister H (1724) Abriss vom Hochfürstl. Hessischen Rheinhartswald mit denen darumb liegenten Situationes, wie auch die neuen angelegten Aleen und Schneisen. Landgrafschaft Hessen-Cassel, Cassel

Samojlik T, Jędrzejewska B, Michniewicz M, Krasnodębski D, Dulinicz M, Olczak H, Karczewski A, Rotherham ID (2013) Tree species used for low-intensity production of charcoal and wood-tar in the 18th-century Białowieża Primeval Forest, Poland. Phytocoenologia 43:1-12. doi:10.1127/0340-269X/2013/0043-0511

Schäfer K (1977) Die Geschichte der Eisenindustrie in der ehemaligen Grafschaft Waldeck im 16. und 17. Jahrhundert. Selbstverlag des Verfassers, Korbach

Schenk W (1996) Waldnutzung, Waldzustand und regionale Entwicklung in vorindustrieller Zeit im mittleren Deutschland - Historisch-geographische Beiträge zur Erforschung von Kulturlandschaften in Mainfranken und Nordhessen. Erdkundliches Wissen 117:1-325

Schott D (1997) Einführung: Energie und Stadt in Europa. Von der vorindustriellen "Holznot" bis zur Ölkrise der 1970er Jahre. In: Schott D (ed) Energie und Stadt in Europa. Von der vorindustriellen "Holznot" bis zur Ölkrise der 1970er Jahre, Steiner, Stuttgart, pp 7-42

Schwappach A (1886) Handbuch der Forst- und Jagdgeschichte Deutschlands. Julius Springer, Berlin

Schwedes PL (1983) Lebenserinnerungen eines Sababurger Rentmeisters und Burggrafen. Jahrbuch Landkreis Kassel, Kassel, pp 62-69

Seidensticker A (1896) Rechts- und Wirthschafts-Geschichte norddeutscher Forsten besonders im Lande Hannover. Zweiter Band: Geschichte der Forsten. Dieterich'sche Universitäts-Buchhandlung, Göttingen 
Sippel K (2005) Wirtschaftsarchäologische Geländeforschungen zum mittelalterlichen und neuzeitlichen Bergbau und Hüttenwesen in Nordhessen. Zeitschrift für Archäologie des Mittelalters 33:103-122 Sippel K (2009) Aschenbrennereien - eine neue Gattung von Bodendenkmälern im Wald. Arbeitsstätten der Neuzeit bei Edertal-Gellershausen und Bad Wildungen-Frebershausen, Landkreis Waldeck-Frankenberg, sowie SontraBlankenbach, Werra-Meißner-Kreis. In: Archäologische und Paläontologische Denkmalpflege des Landesamtes für Denkmalpflege Hessen (ed) HessenArchäologie 2008 - Jahrbuch für Archäologie und Paläontologie. KonradTheiss-Verlag, Stuttgart, pp 159-162

Speier M (1994) Vegetationskundliche und paläoökologische Untersuchungen zur Rekonstruktion prähistorischer und historischer Landnutzungen im südlichen Rothaargebirge. Abhandlungen aus dem Westfälischen Museum für Naturkunde 56:1-174

Stephan H-G (2010) Der Solling im Mittelalter. Archaeotopos-Verlag, Dormagen Succow M, Knapp HD, Jeschke L (2012) Naturschutz in Deutschland: Rückblicke Einblicke - Ausblicke. Christoph Links Verlag, Berlin

Tasche H (1849) Geschichte des Thalitterer Kupfer-Werks. Zweiter Bericht der Oberhessischen Gesellschaft für Natur- und Heilkunde, Giessen, pp 1-12

Venables WN, Ripley BD (2002) Modern applied statistics with S, 4th edn. Springer, New York

Vološčuk I (2014) Joint Slovak-Ukraine-Germany beech ecosystems as the World Natural Heritage. Ekologia 33:286-300. doi:10.2478/eko-2014-0027

von Berg CHE (1844) Das Verdrängen der Laubwälder im nördlichen Deutschlande durch die Fichte und die Kiefer. C. W. Leske, Darmstadt von Berg CHE (1860) Anleitung zum Verkohlen des Holzes. Ein Handbuch für Forstmänner, Hüttenbeamte, Technologen und Cameralisten, 2nd edn. Eduard Zernin, Darmstadt

von Carlowitz HC (1732) Sylvicultura oeconomica oder Haußwirthliche Nachricht und Naturmäßige Anweisung zur Wilden Baum-Zucht, 2nd edn. Johann Friedrich Brauns, Leipzig

von Le Coq CL (1805) Topographische Karte in XXII Blaettern den grösten Theil von Westphalen enthaltend [...], Section XX: Karte des südlichen Theils vom Fürstenthum Waldeck, so wie des angrenzenden Landes bis Cassel. Heinrich Brose, Berlin

Waldeyer K (2014) Die historischen Landesgrenzsteine Waldecks. Waldeckische Forschungen 20:1-300

Warde P (2006) Fear of wood shortage and the reality of the woodland in Europe, c. 1450-1850. Hist Workshop J 62:28-57

Wick W (1910) Die landesherlichen Eisenhütten und Hämmer des ehemaligen Kurhessen bis zum Ende des XVII. Jahrhunderts. Mit einem Rückblick auf die ältere Eisengewinnung. Schönhoven, Kassel

Zarges W (1999) Das Hochgewälde am Edersee: Die Geschichte von Forst, Wild und Jagd in der ehemaligen Herrschaft Itter. Frankenberger Hefte 7:1-88

\section{Submit your manuscript to a SpringerOpen ${ }^{\circ}$ journal and benefit from:}

- Convenient online submission

- Rigorous peer review

- Immediate publication on acceptance

- Open access: articles freely available online

- High visibility within the field

Retaining the copyright to your article 